УДК 343.2

DOI https://doi.org/10.32782/2524-0374/2021-5/78

\title{
COMPLICITY IN A CRIMINAL OFFENSE UNDER THE LAWS OF SOME EASTERN EUROPEAN COUNTRIES
}

\section{СПІВУЧАСТЬ У КРИМІНАЛЬНОМУ ПРАВОПОРУШЕННІ ЗГІДНО ЗАКОНОДАВСТВА КРАЇН СХІДНОЇ ЄВРОПИ}

\author{
Soloviova Alina, doctor of law, \\ Professor of Criminal Law, criminology, civil and commercial law, \\ Vice-Rector for International Cooperation, \\ National Academy of Management
}

Автор статті аналізує співучасть як один з найважливіших інститутів кримінального права, відомий за законодавством всіх країн світу. У статті наголошується, що спільного підходу до визначення та змісту цього інституту в світі немає. Робиться висновок про те, що Кримінальні кодекси країн Східної Європи визнають умисна спільна участь двох або більше осіб у вчиненні умисного злочину співучастю в злочині.

Сам факт вчинення злочинних дій кількома особами в одному місці, одночасно, і навіть коли вони усвідомлюють участь один одного (так звана механічна «комбінація» злочинців), не формує співучасті, якщо дії ці особи не пов'язані між собою (наприклад, вчинення масових заворушень, хуліганські дії, розкрадання чужим майном окремими учасниками).

Співучасть - один із найважливіших інститутів кримінального права, відомий законодавству всіх країн світу. Однак у світі немає загального підходу до визначення та змісту цього інституту. Кримінальні кодекси країн Східної Європи визнають співучасть у вчиненні умисного злочину умисною спільною участю двох або більше осіб.

Відповідно до методу об'єднання спільних зусиль співучасників у процесі вчинення злочину теорія кримінального права розрізняє дві форми співучасті: а) просту співучасть, тобто співучасть без розподілу ролей; б) складну співучасть, тобто співучасть з розподілом ролей.

Перший підхід базується на так званій теорії еквівалентності, яка розглядає кожного учасника злочину як виконавця, не враховуючи характеру його дій у діянні. Критерієм кримінально -правового значення дій окремих спільників є лише причинно -наслідковий зв'язок діяння зі злочинним результатом. Іноді законодавство вводить принцип єдиного виконавця як виняток із загального правила стосовно будь -якої дії чи форми співучасті. Наприклад, згідно з частиною 9 ст. 18 КК Білорусі, учасники організованої групи та злочинна організація визнаються виконавцями, незалежно від їх ролі у скоєних злочинах.

Другий підхід, більш широко використовуваний у країнах Східної Європи, виділяє різні види співучасті.

Ключові слова: кримінальне право, співучасть, злочин, кримінальне правопорушення, країни Східної Європи.

The author of the article investigates complicity as one of the most important institutions of criminal law, known under the laws of all countries of the world. The article notes that there is no general approach to the definition and content of this institution in the world. It is concluded that the Criminal Codes of Eastern European countries recognize the intentional joint participation of two or more persons in the commission of an intentional crime as complicity in a crime.

The very fact of committing criminal acts by several persons in the same place, at the same time, and even when they are aware of each other (the so-called mechanical «combination» of criminals), does not form complicity if the actions of these persons are not interconnected (for example, the commission of mass riots, hooligan actions, theft of other people's property by individual participants).

Complicity is one of the most important institutions of criminal law, known to the legislation of all countries of the world. However, there is no general approach to the definition and content of this institution in the world. The criminal codes of the Eastern European countries recognize the intentional joint participation of two or more persons in the commission of an intentional crime as complicity in crime.

According to the method of combining the joint efforts of accomplices in the process of committing a crime, the theory of criminal law distinguishes 2 forms of complicity: a) simple complicity, i.e. complicity without the distribution of roles; b) complex complicity, i.e. complicity with the division of roles.

The first approach is based on the so-called theory of equivalence, which considers each participant in the crime as an executor, not taking into account the nature of his actions in the act. The criterion of the criminal legal significance of the actions of individual accomplices is only the causal relationship of the deed with the criminal result. Sometimes the principle of a single executor is introduced by the legislator as an exception to the general rule regarding any act or form of complicity. For example, according to part 9 of art. 18 of the Criminal Code of Belarus, participants in an organized group and criminal organization are recognized as executors, regardless of their role in the crimes committed.

The second approach is more used in Eastern European countries distinguishes different types of complicity.

Key words: criminal law, complicity, a crime, a criminal offense, the Eastern European countries.

Criminal complicity is the wilful co-participation of several criminal offenders in an intended criminal offence.

This definition includes the most typical features: participation in the same crime of two or more persons; intentional activities of partners. According to the criminal law doctrine of post-Soviet countries, complicity in crime implies joint actions of the accomplices both in the objective and subjective sides. The objective side is a causal relationship between the actions of accomplices and the commission of the crime while the subjective side is intentional participation in the commission of only an intentional crime.

The very fact of committing criminal acts by several persons in the same place, at the same time, and even when they are aware of each other (the so-called mechanical «combination» of criminals), does not form complicity if the actions of these persons are not interconnected (for example, the commission of mass riots, hooligan actions, theft of other people's property by individual participants).
According to the method of combining the joint efforts of accomplices in the process of committing a crime, the theory of criminal law distinguishes 2 forms of complicity: a) simple complicity, i.e. complicity without the distribution of roles; b) complex complicity, i.e. complicity with the division of roles.

The first approach is based on the so-called theory of equivalence, which considers each participant in the crime as an executor, not taking into account the nature of his actions in the act. The criterion of the criminal legal significance of the actions of individual accomplices is only the causal relationship of the deed with the criminal result. Sometimes the principle of a single executor is introduced by the legislator as an exception to the general rule regarding any act or form of complicity. For example, according to part 9 of art. 18 of the Criminal Code of Belarus, participants in an organized group and criminal organization are recognized as executors, regardless of their role in the crimes committed. 
The second approach is more used in Eastern European countries distinguishes different types of complicity.

The following types of crime participants are distinguished in the criminal law of Easter European countries:

Performer, abettor and accomplice (Bulgaria, Hungary, Poland);

Organizer, performer, abettor and accomplice (Ukraine, Russia, Belarus, Moldova, Latvia, Lithuania, Slovakia, Czech Republic).

We should pay attention to the fact that each Criminal Code has its own system of definitions. As a result, the borders between various types of criminal activity are shifted within the framework of complicity in one direction or another.

According to the Criminal Code of Ukraine, Performer is the person who, in association with other criminal offenders, has committed a criminal offence directly or through other persons, but who cannot be criminally liable. The close approach applies in Belarus, Russia, Moldova, Bulgaria, and Hungary.

The main characteristic of the performer is the direct commission of a crime, i.e. direct execution of the objective side of the corresponding crime. Other accomplices of the crime (organizer, abettor, accomplice), unlike the performer, do not directly perform actions that form the objective side of the crime, they contribute to the commission of a crime.

Organizer as a type of perpetrators of crimes is common for the Criminal Codes of Eastern Europe. According to the Criminal Code of Ukraine, Russia, Belarus, Moldova, Slovakia, Lithuania, the organizer is the person who organized the crime or directed the commission of a criminal offence.

Accessory is person who assisted in committing a crime with advice, instructions, providing information, means, tools, removing obstacles, as well as a person who promised to conceal an offender, instruments or means of committing a crime in advance, buy or sell such things, or otherwise facilitate the covering up of a criminal offence. This definition is given in the Criminal Code of Russia, Belarus, Ukraine, Bulgaria, Moldova, Lithuania, Latvia.

The criminal code of Estonia has a different approach An aider (accessory) is a person who intentionally provides physical, material or moral assistance to an intentional unlawful act of another person. (Article 22, part 3)

In some Eastern European countries, such as Ukraine, Russia, Bulgaria, Hungary, Romania, Lithuania, Latvia, and Estonia, the role of accessory is determined depending on whether the concealment was promised in advance or not. If any sort of help was not promised in advance, it is an independent crime provided for in the Special Part of the Criminal Code.

A decided to commit the murder of his neighbour B. For this purpose, he asked the gun from his friend $\mathrm{C}$, who was an avid hunter. $\mathrm{C}$ gave a gun and ammunition to his friend. In addition, to achieve the result, $\mathrm{C}$ even gave $\mathrm{A}$ a few shooting lessons. At the last moment, A changed his mind about killing a neighbour with a gun and used poison, which he added to his neighbour's food when he invited him to his dinner. Will $\mathrm{C}$ be recognized as an accomplice in the murder of neighbour B?

This murder, committed by 'A', cannot be considered committed in complicity. ' $C$ ' helped 'A', providing him with tools for the commission of the murder, namely - a gun. However, the performer did not take advantage of the assistance provided to him and committed a crime using poison. ' $\mathrm{C}$ ' cannot be considered an accomplice to the murder since his act was not a necessary condition for the onset of the socially dangerous consequences of the crime committed. ' $\mathrm{C}$ ' should be responsible for preparing for the murder.

Abettor is a person who by any means makes another person commit a crime. This definition is the most common in the Criminal Codes of Eastern European countries.

The Criminal Code of Ukraine specifies the means by which abettor induces any other accomplice to a criminal offence, namely by persuasion, subornation, threat, coercion or otherwise.
$\mathrm{N}$, who lived together with her daughter-in-law $\mathrm{F}$ and her son $\mathrm{B}$, was constantly finding fault with the daughter-in-law and created unbearable living conditions for her. $\mathrm{N}$ deliberately through away the food that $\mathrm{F}$ cooked, hid her things, $\mathrm{N}$ constantly complained about her daughter-in-law to his son who sometimes beat $F$. During the next quarrel between $F$ and $\mathrm{B}, \mathrm{B}$ killed his wife with an axe. Can mother-in-law $\mathrm{N}$ be considered the abettor of this murder?

In this case, there is no causal connection between the act of the accomplice and the act of the perpetrator ' $\mathrm{B}$ '. The actions of ' $\mathrm{N}$ ', did not include persuasion, subornation, threat, coercion or other forms of inducing the son to commit the murder of his wife ' $F$ '.

As we see from the above example, the activity of the abettor should have the consequences of the performer committing the criminal offence. The causal connection between the act of the instigator and the socially dangerous consequence of the crime is indirect in nature, developing according to the principle causa causae est causa causati - "the cause of the cause is the cause of the result".

Most of the criminal codes analysed establish the same responsibility for performers and other accomplices. However, the indication on the equal liability of accomplices does not preclude individualization of punishment, since the latter is determined by the court for each perpetrator, taking into account the circumstances of a particular case. According to the article 19 of the Criminal Code of Poland, in imposing the penalty for aiding and abetting, the court may apply extraordinary mitigation of punishment.

In the theory of criminal law in most countries of Eastern Europe, there are two main theories of the grounds for criminal liability of accomplices.

According to the first theory, known as the accessory theory (from the Latin 'accessorium' - additional, nonindependent), complex accomplices, that is, the organizer, instigator and accomplice, do not have an independent basis of criminal responsibility. The basis for their responsibility is a crime committed by the performer. Accomplices take part in an "another's" crime, the main criminal of which is the performer, therefore the criminal activity of the organizer, instigator and accomplice has not independent, but only additional, subordinate significance in relation to the criminal activity of the performer.

Another theory of liability for complicity, based on the theory of the independent responsibility of partners. It, on the contrary, proceeds from the fact that the basis of the criminal liability of each of the partners is independent. "Each accomplice is subject to criminal liability on the basis that he, acting guilty, encroaches on public relations protected by criminal law... his personal activities, therefore, become socially dangerous. Each accomplice, whether he acts alone or together with other persons, committing a crime, thereby creates the basis of his criminal responsibility.

The current criminal law in regulating the liability of accomplices is based on a combination of both theories. On the one hand, the Criminal Codes recognize the accessory nature of complicity and emphasize the impossibility of complicity without a performer. On the other hand, the Criminal Codes establish different criminal liability for accomplices in some cases, determining an individual measure of responsibility for each of them, depending on the nature and degree of actual participation in the commission of the crime.

Based on this combination, liability for complicity in a crime is possible only if there is a basis for the responsibility of the performer (the crime committed by him). On the contrary, the exclusion of the responsibility of the performer (for example, by virtue of his voluntary refusal, commission of an insignificant act) makes the liability of other persons impossible according to the rules about complicity, although this does not exclude their independent responsibility for an individually committed criminal act. 
Another issue in imposing the penalty is the so-called excess of the performer.

The excess of the performer is determined when the perpetrator committing a crime not covered by the intent of other accomplices. Therefore, the performer independently goes beyond previously agreed intention and commits a more serious crime.

The criminal law of most Eastern European countries establish a common approach. When one of the accomplices goes beyond the scope of the agreement and commits a more serious or other crime, only the perpetrator should be responsible for this crime, while other persons are only responsible for the crimes committed within the framework of the agreement.

For example, two persons agreed to cause the injury to a victim, one of them, being a performer of this crime, deprived life of the victim. In this case, the performer is liable for murder, while the other accomplice - only for causing an injury.

According to part of article 28 of the Criminal Code of Ukraine, a criminal offence shall be held to have been committed by a group of persons when two or more offenders participated in that criminal offence, acting without prior conspiracy.

In part 1 of article 35 of the Criminal Code of the Russian Federation, a crime shall be deemed to be committed by a group of persons if two or more perpetrators have jointly participated in its commission without previous concert.

In the concept of a group of persons, the sign "two or more performers" has a qualitative and quantitative characteristic. With a quantitative description, everything is quite simple. The group of performers must have more than one person (several people). Their maximum number is not defined by law, therefore, it can be any amount.

It is more complicated to define the qualitative characteristic of the generic attribute of the concept of a group of persons. It is necessary to decide who the performer is in this case and whether he is the subject of a crime

The issue of qualification of a crime which is committed by a perpetrator that acts together with a person who is not the subject of a crime (for example, a person who has not reached the age of criminal responsibility, an insane person) is controversial among scholars of Eastern European countries.

In paragraph 9 of the Decree of the Plenum of the Supreme Court of the Russian Federation of 04.22.1992 No. 4 (as amended on 12.21.1993) "On judicial practice in cases of rape", it was stated that the actions of accomplices should be qualified regardless of the age or sanity of participants. In paragraph 9 of the Decree of the Plenum of the Supreme Court of the Russian Federation of February 14, 2000 No. 7 (as amended on February 6, 2007) "On judicial practice in cases of juvenile crimes" was explained that a crime committed with a person under the age of criminal liability or insane person would not constitute complicity.

The necessary characteristics of a crime committed by a group are: 1) features that are inherent in complicity as a generic concept, 2) specific features of a group.

A group cannot be considered criminal if the perpetrator commits an act together with an inappropriate subject. Therefore, in the case when out of the group of persons who committed the crime, only one person is the subject of the crime, and the rest of the persons cannot be the subjects of the crime, this crime cannot be qualified as a crime committed by a group of persons.

$\mathrm{J}$ decided to get revenge on $\mathrm{K}$. For this purpose, he turned $\mathrm{T}$, who was declared, against $\mathrm{K}$. J persuaded $\mathrm{T}$ to stab K, gave him a knife, and led him to the place where $\mathrm{K}$ used to walk. $\mathrm{T}$ implemented John's plan and killed $\mathrm{K}$ with a knife. How, in this case, will the presence of two people be taken into account when committing this criminal act?

There is no complicity in this case since two people committed the crime, however, only one of them is the subject of the crime, namely 'J'. 'J' will be responsible for the intentional murder of ' $\mathrm{K}$ '

The approach is the same if the perpetrator resorted to the help of a minor, it does not form a criminal group due to the lack of features defining qualitative features of a criminal group.

In the case of delusion, when the perpetrator did not realize that he had combined his efforts with the minor, the deed should be evaluated according to the rules of factual error, that is, as an attempt on a more dangerous type of crime an encroachment by a group of people.

A criminal offence shall be held to have been committed by a group of persons upon prior conspiracy where it was jointly committed by several (two or more) persons who have conspired in advance, prior to the commencement of the offence, to commit it together (Part 2 of Article 28 of the Criminal Code of Ukraine).

A worked as a security guard at a large company manufacturing sausages. A decided to steal meat and offal. During one of his duties, he carried out of the freezer and hid in his utility room 7 bags of offal and $20 \mathrm{~kg}$ of meat. A realized that it would be difficult to carry it. So the next day, he invited his two friends - B and C, to take part in the theft. A day later, they took 7 bags of offal and $20 \mathrm{~kg}$ of meat from the company's territory.

How should the actions of the three guilty persons A, B and $\mathrm{C}$ be evaluated from the point of view of the criminal institution of complicity in the form of a group upon prior conspiracy?

Based on the quantitative characteristics of the group, then three people are enough to form a group. There is no doubt about the joint efforts to carry out actions to seize other people's property. However, there are some remarks regarding the sign of "prior" conspiracy. In order to make a correct conclusion about the signs of "a group upon prior conspiracy", it is necessary to accurately understand the moment the crime began and determine the moment of the initial actions that are part of the objective side of the crime. Obviously, conspiracy is possible at the stage of preparation for the commission of a crime. If we consider our example, then 'A' has already begun to act in order to seize someone else's property, and at the time of asking ' $\mathrm{B}$ ' and ' $\mathrm{C}$ ' for help, there was an unconsummated attempt to steal. Therefore, the actions of 'A', 'B', 'C' has characteristics of a group, but there is no sign of "prior" conspiracy.

According to the Criminal Code of Ukraine, a group of persons committed upon prior conspiracy is considered to be a premeditated murder when several people (two or more) took part in the deprivation of the victim's life. The accomplices were in advance (before the crime) agreed on a joint implementation. (Section 12, Part 2 of Art. 115 of the Criminal Code of Ukraine)

Those who although they did not commit acts that directly caused the death of the victim, but carried out some actions that the group considered necessary to implement this intent are also responsible for this crime.

If the members of the group acted in concert, although each of them took the life of one victim, the actions of each of the accomplices are considered as the intentional murder upon prior conspiracy.

The Plenum of the Supreme Court of the Russian Federation also clarifies that murder is recognized as a crime committed by a group of people, when two or more persons, acting with the intent to commit the murder, were directly involved in the process of depriving life by using violence against the victim. It is not necessary that the damages resulting deaths were caused by each of them (for example, one suppressed the victim's resistance, deprived him of the opportunity to defend himself, and the other caused him injuries).

It was established that 'A', together with 'B', began to beat ' $\mathrm{X}$ ', inflicting blows to various parts of his body. After that, the victim was taken to the riverbank, where ' $A$ ' struck 
several blows on the head of ' $\mathrm{X}$ ' with a stone. ' $\mathrm{B}$ ' struck the throat of ' $\mathrm{X}$ ' with a broken bottle. According to the report of a forensic medical examination, ' $X$ "s death occurred as a result of a combination of the main injury (multiple cut wounds to the neck), and an open head injury, accompanied by profuse blood loss, contusion and swelling of the brain. The actions of ' $\mathrm{B}$ ' and ' $\mathrm{A}$ ' are qualified by the court under subsection " $\%$ " of part 2 of article 105 of the Criminal Code of the Russian Federation as a murder committed by a group of persons (determination No. 66-O10-154).

The crime was committed in a group of persons upon prior conspiracy, an agreement on which was reached before the start of the crime. In addition, a mandatory feature of a criminal group is a bilateral subjective relationship and consistency of behaviour. Members of the group with or without separation of roles show a fundamental readiness to perform any function dictated by the nature of the crime.

There is a distinction between an organized group and a criminal organization in Ukraine, Russia, Moldova, Belarus, and Lithuania.

In other countries, the concept of "criminal organization" ("criminal community", etc.) covers all types of organized criminal associations, regardless of the degree of complexity of their internal organization. This approach is represented in Latvia.

According to the Criminal Code of Ukraine, a criminal offence shall be held to have been committed by an organized group where several persons (three or more) participated in its preparation or commission, who have previously established a stable association for the purpose of committing of this and other offence (or offences), and have been consolidated by a common plan with assigned roles designed to achieve this plan known to all members of the group (Part 3, Article 28)

The subject of a crime committed by an organized group can be recognized only as a person who is a member of such an association, not only who was one of the perpetrators of the crime, but also the one who prepared it. Therefore, when the activities of an organized group were suspended at the stage of preparation of the crime, or one or two of its participants made preparations for the commission of the crime, the courts should qualify the crime as committed by an organized group. In part 3 of article 35 of the Criminal Code of the Russian Federation, a crime shall be deemed to be committed by an organised group if it was committed by a stable group of persons who in advance united for the commission of one or more offences.

Galiakbarov (2000), characterizing the signs of an organized group, indicates that «sustainability» is the main one. At the same time, he draws attention to the error of practitioners who consider sustainability as conspiracy, which itself is a condition of complicity. The stability of an organized criminal group lies in its ability to ensure the stability of its functioning, that is, effectively counteract the factors that can disorganize it, both internally and externally. A group can be recognized as stable only if it is cohesive. The cohesion of the group is manifested in the constant strong internal relations between the group members, their rules of conduct, the organizer, a clear definition of the roles of each participant, a high level of coordination of the actions of the participants, and a single plan that distributes functions of the group members. The stability of the group is also the ability to replace participants, cover up their activities, both on their own and with the help of others, the availability of financial and other material resources for the functioning of the group. However, the main goal of the organizer of such groups is the formation of a stable association of persons for engaging in criminal activity, ensuring the relationship between the actions of all participants, streamlining the interaction of its structural ties.

The court noted that the factual basis for qualifying the actions of the convict was evidence that, guided by a selfish motive and in order to commit theft, he organized internally stable organization and took the role of the leader of this group. At the same time, the convict planned and organized the commission of crimes, distributed the functions among the group members that they held in accordance with the plan during the commission of the crimes and which were interconnected aimed at the objective side of these crimes, coordinated their actions, distributed among the participants of the organized group based on the results of committing crimes money (decision of 11/14/2018 in case No. 484/1134/16-k).

A criminal offence shall be held to have been committed by a criminal organization where it was committed by a stable hierarchical association of several persons (five and more), members or structural units of which have organized themselves, upon prior conspiracy, to jointly act for the purpose of directly committing of grave or special grave criminal offences by the members of this organization, or supervising or coordinating criminal activity of other persons, or supporting the activity of this criminal organization and other criminal groups (part 4 of article 28 of the Criminal Code of Ukraine).

Complicity is one of the most important institutions of criminal law, known to the legislation of all countries of the world. However, there is no general approach to the definition and content of this institution in the world. The criminal codes of the Eastern European countries recognize the intentional joint participation of two or more persons in the commission of an intentional crime as complicity in crime.

\section{REFERENCES}

1. Criminal Code of Belarus. URL:https://cis-legislation.com/document.fwx?rgn=1977 (дата звернення - 21.02.2021).

2. Criminal Code of the Republic of Bulgaria. URL: https://www.legislationline.org/download/id/8395/file/Bulgaria_Criminal_Code_1968_ am2017 ENG.pdf (дата звернення - 21.02.2021).

3. Criminal Procedure Code of the Czech Republic. (English version). URL: https://www.legislationline.org/download/id/6370/file/Czech\%20 Republic CC 2009 am2011 en.pdf (дата звернення - 21.02.2021).

4. Criminal Code of the Republic of Hungary. URL: https://www.legislationline.org/documents/section/criminal-codes/country/25/Hungary/ show (дата звернення - 21.02.2021).

5. Criminal Law of the Republic of Latvia. URL: https://www.legislationline.org/download/id/8266/file/Latvia_CC_1998_am2018_en.pdf (дата звернення - 21.02.2021).

6. Criminal Code of Lithuania. URL: https://www.legislationline.org/documents/section/criminal-codes/country/17/Liechtenstein/show (дата звернення - 21.02.2021)

7. Criminal Code of the Republic of Moldova. URL: https://www.legislationline.org/download/id/8281/file/Moldova_CC_2002_am2018_ en.pdf (дата звернення - 21.02.2021).

8. Criminal Code of the Republic Poland. URL: https://www.legislationline.org/download/id/7354/file/Poland_CC_1997_en.pdf (дата звернення - 21.02.2021).

9. Criminal Code of the Republic of Romania. URL: https://www.legislationline.org/download/id/8291/file/Romania_Penal\%20Code_ am2017 en.pdf (дата звернення - 21.02.2021).

10. Criminal Code of the Russian Federation. URL: https://www.legislationline.org/download/id/4247/file/RF_CC_1996_am03.2012_en.pdf (дата звернення - 21.02.2021).

11. Criminal Code of the Slovak Republic. (English version). URL: https://www.legislationline.org/download/id/3763/file/Slovakia CC 2005 en.pdf (дата звернення - 21.02.2021). 
12. Criminal Code of Ukraine (Ukrainian version). URL: https://zakon.rada.gov.ua/laws/show/2341-14 (дата звернення - 21.02.2021).

13. Galiakbarov R.R. Kvalifikaciya prestuplenij po priznaku ix soversheniya organizovannoj gruppoj [Qualification of crimes on the basis of their commission by an organized group] Rossijskaya yusticiya. 2000. 4 .

14. Penal Code of Estonia. URL: https://www.legislationline.org/download/id/8244/file/Estonia_CC_am2019_еn.pdf (дата звернення 21.02.2021).

15. Soloviova A. (2019). Law: basic aspects: [textbook]. Vinnytsia. 80 p.

16. Kryminalnyj kodeks Ukrainy: naukovo-praktychnyj komentar. (2012). [Criminal code of Ukraine: scientific and practical commentary] Vydannia vosme, pereroblene ta dopovnene / Vidp. red. Ye.L. Strel'tsov, Odisej [in Ukrainian]. 